\title{
Distribution of pfmdr1 polymorphisms in Plasmodium falciparum isolated from Southern Thailand
}

\author{
Mathirut Mungthin ${ }^{1 *}$, Somchai Intanakom², Nantana Suwandittakul ${ }^{1}$, Preeyaporn Suida ${ }^{3}$, Sakultip Amsakul ${ }^{4}$, \\ Naruemon Sitthichot ${ }^{1}$, Suwich Thammapalo ${ }^{2}$ and Saovanee Leelayoova ${ }^{1}$
}

\begin{abstract}
Background: Drug resistance in Plasmodium falciparum is a major problem in malaria control especially along the Thai-Myanmar and Thai-Cambodia borders. To date, a few molecular markers have been identified for anti-malarial resistance in $P$. falciparum, including the $P$. falciparum chloroquine resistance transporter ( $p f c r t)$ and the $P$. falciparum multidrug resistance 1 (pfmdr1). However no information is available regarding the distribution pattern of these gene polymorphisms in the parasites from the Thai-Malaysia border. This study was conducted to compare the distribution pattern of the pfcrt and pfmdr1 polymorphisms in the parasites from the lower southern provinces, Thai-Malaysia border and the upper southern provinces, Thai-Myanmar border. In addition, in vitro sensitivities of anti-malarial drugs including chloroquine, mefloquine, quinine, and artesunate were determined.
\end{abstract}

Methods: In all, 492 P. falciparum-positive blood samples were collected from the lower southern provinces: Songkhla, Yala and Narathiwas. From the upper southern part of Thailand, Ranong and Chumphon, 66 samples were also collected. Polymorphisms of the pfcrt and the pfmdr1 gene were determined using PCR techniques. In vitro sensitivities of anti-malarial drugs were determined using radioisotopic method.

Results: All parasites from both areas contained the pfcrt $76 \mathrm{~T}$ allele. The pfmdr1 86Y allele was significantly more common in the parasites isolated from the lower southern areas. In contrast, the pfmdr1 184F allele was predominant among the parasites from the upper southern areas especially Ranong. In addition, the parasites from Ranong contained higher copy numbers than the parasites from other provinces. All adapted parasite isolates exhibited CQ-resistant phenotype. Neither QN nor MQ resistance was detected in these isolates.

Conclusion: The parasites from Thai-Malaysia border exhibited different resistant patterns compared to other areas along the international border of Thailand. This information will be useful for anti-malarial drug policy in Thailand.

\section{Background}

Multidrug resistance in Plasmodium falciparum has been a major problem in malaria control along the international borders of Thailand especially, Thai-Myanmar and Thai-Cambodia border [1]. Artemisinin-based combination therapy (ACT), using a combination of artesunate (ART) and mefloquine (MQ), has been introduced for the treatment of uncomplicated falciparum malaria to address this problem [2]. In the past few years, emergence of artemisinin resistance in these areas is a matter of concern

\footnotetext{
*Correspondence: mathirut@pmk.ac.th

'Department of Parasitology, Phramongkutklao College of Medicine,

Ratchawithi Rd, Bangkok 10400, Thailand

Full list of author information is available at the end of the article
}

$[3,4]$. Prolonged parasite clearance has now been used as the indicator of artemisinin resistance [4].

A few molecular markers have been identified for antimalarial resistance in $P$. falciparum. The $P$. falciparum chloroquine resistance transporter $(p f c r t)$ has been identified as the main determinant of chloroquine (CQ) resistance [5]. A point mutation on the pfcrt gene resulting in replacement of lysine by threonine in the PfCRT at codon 76 has been linked to CQ resistance in parasite isolates collected worldwide [6]. The P. falciparum multidrug resistance 1 (pfmdr1), a gene on chromosome 5 encoding a P-glycoprotein homologue 1 (pgh1) also contributes to CQ resistance [7-10]. Several studies have shown that single nucleotide polymorphisms and amplification of the 
pfmdr1 gene is also associated with in vitro response and clinical efficacy of MQ, an arylaminoalcohol [11-14]. Evidence suggests that the $p f m d r 1$ gene plays a role in the in vitro response to other quinolines such as quinine $(\mathrm{QN})$ and lumefantrine (LF) and artemisinin derivatives [15-18].

To date, the distribution of the pfcrt and pfmdr1 polymorphisms were only reported in the parasites collected from the Thai-Myanmar and Thai-Cambodia borders, but not the Thai-Malaysia border $[10,13,14,17,18]$. Since different patterns of $p f c r t$ and $p f m d r 1$ polymorphisms in $P$. falciparum exhibit varied anti-malarial drug susceptibilities $[10,17,18]$, knowing the distribution of these polymorphisms in these areas would be useful. In this study, the pfcrt and pfmdr1 polymorphisms in P. falciparum isolated from the Thai-Malaysia border were determined compared with the parasites isolated from upper southern provinces, Thai-Myanmar border. In addition, the in vitro sensitivities of anti-malarial drugs including $C Q, M Q, Q N$ and ART were determined in recently adapted P. falciparum isolated from this area.

\section{Methods}

\section{Blood sample collection}

Finger-prick blood (approximately $200 \mu \mathrm{l}$ ) samples from patients who visited malaria clinics of the Office of Disease Prevention and Control 12 (the lower southern provinces including Songkhla, Yala and Narathiwas) and the Office of Disease Prevention and Control 11 (the upper southern provinces including Ranong and Chumphon) were collected onto Whatman No 3 filter paper. At these clinics, Giemsa-stained thick film was performed for the diagnosis of malaria. The dried filter paper samples were kept in plastic zipper bags and sent to the Department of Parasitology, Phramongkutklao College of Medicine, for molecular analysis. A total of 492 microscopically positive $P$. falciparum blood samples were collected from three lower southern provinces in 2009. Of these 492 samples, 43, 215 and 234 samples were collected from Songkhla, Yala and Narathiwas, respectively. Sixty-six samples were also collected from the upper southern part of Thailand, i e, 42 samples from Ranong and 24 samples from Chumphon. All these samples were confirmed to be $P$. falciparum positive by PCR technique as described by Snounou et al. [19]. The research protocol was reviewed and approved by the Ethics Committee of the Royal Thai Army Medical Department.

\section{Plasmodium falciparum cultivation and in vitro sensitivity assays}

Fifteen isolates of P. falciparum collected from Yala, a province along the Thai-Malaysia border in 2010 were adapted. Parasites were maintained in continuous cultures using a modification of the method of Trager and Jensen [20]. These isolates were tested against commonly used anti-malarial drugs including $\mathrm{CQ}, \mathrm{MQ}, \mathrm{QN}$ and $\mathrm{ART}$ using radioisotopic assay as previously described [21]. Drug $\mathrm{IC}_{50}$ (i e concentration of a drug which inhibits parasite growth by $50 \%$ ) was determined from the log dose/ response relationship as fitted by GRAFIT (Erithacus Software, Kent, UK). Each in vitro sensitivity experiment was carried out in triplicate. The $\mathrm{IC}_{50}$ of each isolate was the mean $\mathrm{IC}_{50}$ of at least three independent experiments.

\section{Genotypic characterization for pfcrt and pfmdr 1 genes}

Parasite DNA was extracted using the Chelex-resin method [22]. Five $\mu \mathrm{l}$ of DNA preparation was used for a $25 \mu \mathrm{l}$ PCR reaction. PCR and allele-specific restriction analysis were performed for the detection of the pfcrt mutations encoded amino acids at position 76 [23]. Mutations in the pfmdr1 gene were determined by the nested PCR and restriction endonuclease digestion method developed by Duraisingh et al. [15] for detection of the mutations at codons 86, 184, 1034, 1042 and 1246 [24]. K1, a laboratory strain containing the $86 \mathrm{Y}$ allele was used as a control for the detection of the N86Y mutation. For the positive control of the $184 \mathrm{~F}, 1034 \mathrm{C}, 1042 \mathrm{D}$ and $1246 \mathrm{Y}$ alleles, 7G8 strain was used. The results with a combined band pattern of undigested and digested fragments were considered mixed alleles. The $p f m d r 1$ gene copy number was determined by TaqMan real-time PCR (ABI sequence detector 7000; Applied Biosystems) as developed by Price et al. [25]. The K1 and DD2 clone containing 1 and 4 pfmdr 1 copies, respectively, was used as the reference DNA sample. The pfmdr1 and $\beta$-tubulin amplification reactions were run in duplicate. Relative copy number of the $p f m d r 1$ gene was determined as previously described [25].

\section{Statistical analysis}

Data were analysed by STATA/MP, Version 12. Differences of the mean copy number of the pfmdr1 gene among the parasites from different areas were analysed by Independent $t$ test and One-way ANOVA. Post hoc test (Scheffe) for multiple comparisons was used to test for differences among groups. Association between genotypes and P. falciparum from different areas was analysed by Chi square test. The level of significance was set at a $p$ value of $<0.05$.

\section{Results}

\section{Characterization of the pfcrt and pfmdr1 genes}

Genotypic characterization of the parasite isolates from upper and lower southern Thailand is shown in Table 1 and Figure 1. All parasites from both areas contained the pfcrt 76T allele. Of the 492 parasite isolates from lower southern Thailand, 474 (96.3\%), 16 (3.3\%), and two (0.4\%) isolates contained the $p f m d r 186 \mathrm{Y}, 184 \mathrm{~F}$ and $1034 \mathrm{C}$ mutations, respectively. The distribution of the $p f m d r 1$ polymorphisms of the parasites isolated among three lower 
Table 1 Distribution of the pfcrt and pfmdr1 polymorphisms of the parasites isolated from upper and lower southern areas

\begin{tabular}{|c|c|c|c|c|c|c|c|c|}
\hline \multirow[t]{2}{*}{ Area } & \multirow{2}{*}{$\begin{array}{l}\text { No. of } \\
\text { isolates }\end{array}$} & \multirow[t]{2}{*}{ pfcrt 76T } & \multirow{2}{*}{$\begin{array}{l}\text { Mean pfmdr } 1 \\
\text { copy number }\end{array}$} & \multicolumn{5}{|c|}{ pfmdr1 mutations } \\
\hline & & & & $86 \mathrm{Y}$ & $184 \mathrm{~F}$ & $1034 C$ & 1042D & $1246 Y$ \\
\hline Upper southern & 66 & $66(100 \%)$ & $2.3 \pm 1.0^{*}$ & $24(36.4 \%)^{* *}$ & $42(63.6 \%)^{* *}$ & $0(0 \%)$ & $0(0 \%)$ & $0(0 \%)$ \\
\hline Ranong & 42 & $42(100 \%)$ & $2.6 \pm 0.8$ & $6(14.3 \%)$ & 36 (85.7\%) & $0(0 \%)$ & $0(0 \%)$ & $0(0 \%)$ \\
\hline Chumphon & 24 & $24(100 \%)$ & $1.7 \pm 0.9$ & $18(75.0 \%)$ & $6(25.0 \%)$ & $0(0 \%)$ & $0(0 \%)$ & $0(0 \%)$ \\
\hline Lower southern & 492 & 492 (100\%) & $1.2 \pm 0.4$ & 474 (96.3\%) & $16(3.3 \%)$ & $2(0.4 \%)$ & $0(0 \%)$ & $0(0 \%)$ \\
\hline Yala & 215 & 215 (100\%) & $1.3 \pm 0.5$ & 204 (94.9\%) & $10(4.7 \%)$ & $2(0.9 \%)$ & $0(0 \%)$ & $0(0 \%)$ \\
\hline Narathiwas & 234 & $234(100 \%)$ & $1.2 \pm 0.4$ & $228(97.4 \%)$ & $5(2.1 \%)$ & $0(0 \%)$ & $0(0 \%)$ & $0(0 \%)$ \\
\hline Songkhla & 43 & $43(100 \%)$ & $1.2 \pm 0.4$ & 42 (97.7\%) & $1(2.3 \%)$ & $0(0 \%)$ & $0(0 \%)$ & $0(0 \%)$ \\
\hline
\end{tabular}

*Significant difference between parasites isolated from upper and lower southern area determined by Independent $t$ test $(p<0.001)$.

**Significant difference between parasites isolated upper and lower southern area determined by Chi square test $(p<0.001)$.

southern provinces, i e Yala, Narathiwas and Songkhla, was similar. The $p f m d r 186 \mathrm{Y}$ allele was significantly more common in the parasites isolated from lower southern areas than those isolated from upper southern areas (Chi square, $p<0.001)$. In contrast, the $p f m d r 1184 \mathrm{~F}$ allele was more common in the parasites from upper southern areas (Chi square, $p<0.001$ ). In this area, the $p f m d r 1184 \mathrm{~F}$ allele was significantly more common in the parasites isolated from Ranong compared to those from Chumphon
(Chi square, $p<0.001$ ). In contrast, the $p f m d r 186 \mathrm{Y}$ allele was significantly predominant in the parasites from Chumphon (Chi square, $p<0.001$ ). Parasites containing mixed alleles of the pfmdr1 gene were not detected in all samples.

Determination of the $p f m d r 1$ gene copy number showed that the isolates from upper southern areas contained the pfmdrl copy numbers with the mean of 2.3 (range 1 to 4 ) which was significantly higher than those found in the

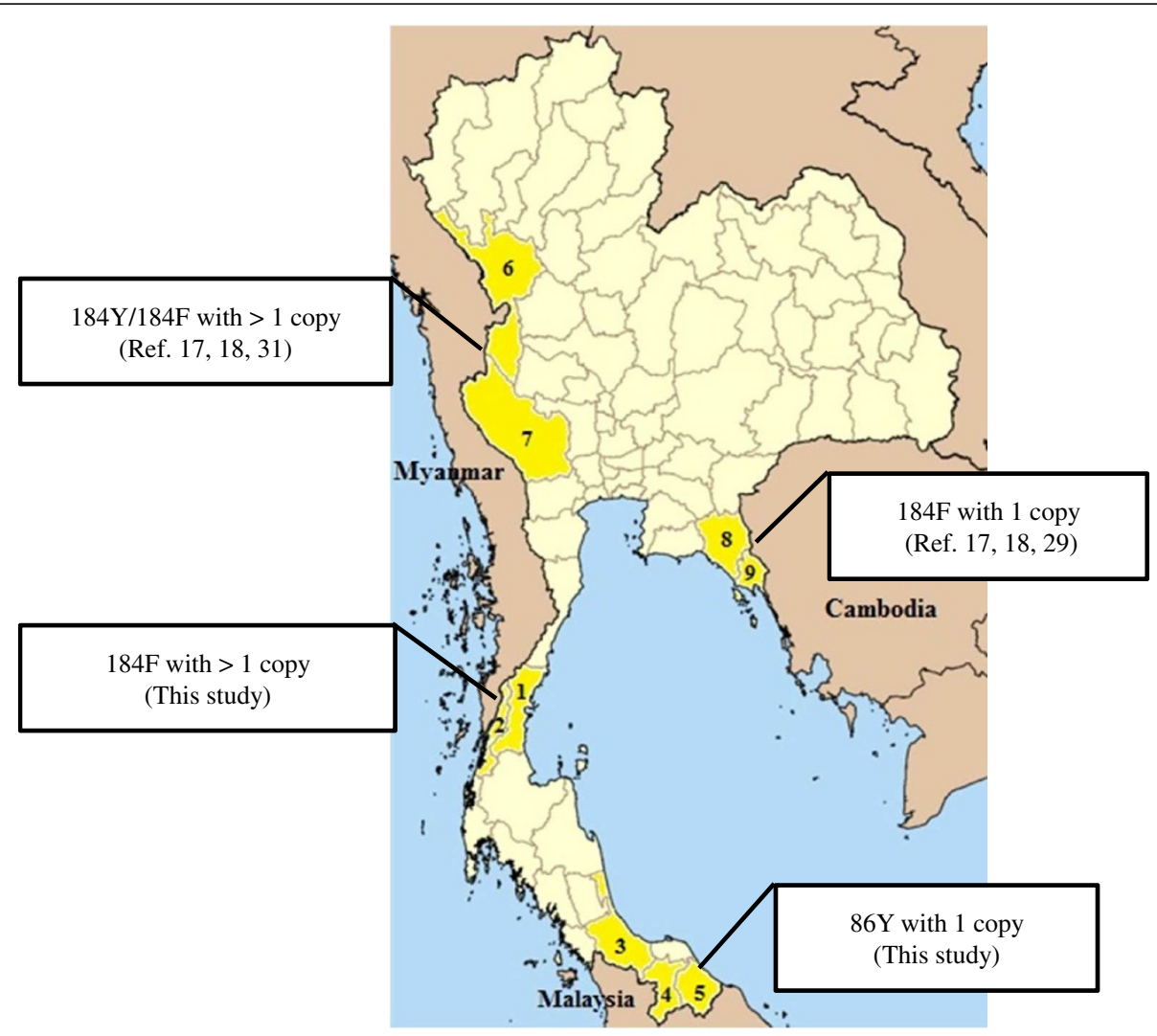

Figure 1 Predominant pfmdr1 genotypes in different areas of Thailand. The present study locations including two provinces in the upper south, (1) Chumphon and (2) Ranong and three provinces in the lower south, (3) Songkhla, (4) Yala and (5) Narathiwas and previously reported areas including (6) Tak and (7) Kanchanaburi [17,18,31], (8) Chantaburi and (9) Trat [17,18,29]. 
parasite from lower southern areas $($ mean $=1.2$, range 1 to 3). Significant differences of the $p f m d r 1$ copy numbers were found among the parasites from different provinces (One-way ANOVA, $p<0.001$ ). Multiple comparison indicated that the parasites from Ranong contain more copy number than the parasites from Chumphon, Yala, Narathiwas and Songkhla (all $p<0.001$ ). The parasites from Chumphon also had more copy number than the parasites from lower southern areas, i e Yala, Narathiwas and Songkhla ( $p=0.007, p=0.004$, and $p=0.012$, respectively).

\section{In vitro anti-malarial sensitivities against 15 Plasmodium falciparum isolates from Yala}

Table 2 shows in vitro response of parasites isolated from Yala to four commonly used anti-malarial drugs. All isolates exhibited CQ-resistant phenotype [26]. Neither QN resistance (QN IC50 of $>800 \mathrm{nM}$ ) [27] nor MQ resistance (MQ $\mathrm{IC}_{50}$ of $>30 \mathrm{nM}$ ) [28] was detected in these isolates. All isolates contained the pfcrt $76 \mathrm{~T}$ and a single copy of the $p f m d r 1$ gene with the $86 \mathrm{Y}$ allele.

\section{Discussion}

Majority of P. falciparum isolates collected from three provinces along the Thai-Malaysia border, i.e. Yala, Narathiwas and Songkhla, contained the pfmdr1 86Y allele (96.3\%) with the mean copy number of 1.2. Malaria cases in the southernmost provinces have significantly increased since 2005, after political unrest in this area. Previously, only a small number of $P$. falciparum isolates collected from this area were genetically characterized. Similar to the present study, Pickard et al. identified the pfmdr1 $86 \mathrm{Y}$ allele in all eight $P$. falciparum isolates from Yala, one of the southernmost provinces [13]. This information indicates the different patterns of the $p f m d r 1$ polymorphisms in $P$. falciparum isolated from different international borders of Thailand. In a few studies of Thai P. falciparum isolates, polymorphisms of the pfmdr1 gene were determined in the parasites mostly collected from either Thai-Myanmar or the Thai-Cambodia borders $[10,13,14,17,18]$. The recently collected parasites from the Thai-Cambodia border contained the pfmdr1 184F allele with a lower copy number compared with the parasites from the Thai-Myanmar border [17,18,29,30]. In contrast, parasites collected from the Thai-Myanmar border usually contained either the $184 \mathrm{Y}$ or $184 \mathrm{~F}$ allele

Table 2 In vitro anti-malarial sensitivities in 15 P. falciparum isolates from Yala

\begin{tabular}{|c|c|c|c|}
\hline & $\operatorname{Min} I C_{50}(\mathrm{nM})$ & $\operatorname{Min} \mathrm{IC}_{50}(\mathrm{nM})$ & Mean $\mathrm{IC}_{50}(\mathrm{nM}) \pm \mathrm{SD}$ \\
\hline Chloroquine & 63.0 & 189.7 & $129.2 \pm 45.2$ \\
\hline Quinine & 102.7 & 278.2 & $185.2 \pm 61.7$ \\
\hline Mefloquine & 10.7 & 24.5 & $16.6 \pm 3.9$ \\
\hline Artesunate & 3.0 & 4.4 & $3.8 \pm 0.5$ \\
\hline
\end{tabular}

with a higher copy number of the pfmdr1 gene [17,18,31]. To compare the parasites collected from these three southernmost provinces, the polymorphisms of the $p f m d r 1$ gene in the parasites from Ranong and Chumphon, provinces along the Thai-Myanmar border, were also determined. Similar to previous studies, most of these parasites, especially those collected from Ranong, had the 184F allele and increased copy number of the pfmdr1 gene. In contrast to the pfmdr1 gene, all the study parasites contained the CQresistant genotype, the $76 \mathrm{~T}$ allele.

The different patterns of the pfmdr1 polymorphisms among the parasites from these international borders of Thailand might be due to the response to a different drug pressure in the past. Since 1995, the combination of ART/ MQ has been adopted by the Ministry of Public Health for the treatment of uncomplicated falciparum malaria in Thailand $[1,32,33]$. In the beginning, this combination was used only in the highly MQ- resistant areas, including the Thai-Myanmar area, Tak and the Thai-Cambodia area, Trat and Chantaburi. In some areas of the Thai-Myanmar border, including Ranong, ART has been added just a few years later. In addition, dosage of ART and MQ might vary among different areas. For example, in 2002, a single dose of $15 \mathrm{mg} / \mathrm{kg}$ of MQ was used in the non- or low MQresistant areas of Kanchanaburi while in the moderateMQ-resistant areas of this province, divided doses of $12 \mathrm{mg} / \mathrm{kg}$ ART were added. In contrast, in the high MQresistant areas such as Mae Sod, Tak province, a combination of $25 \mathrm{mg} / \mathrm{kg}$ of MQ and $12 \mathrm{mg} / \mathrm{kg}$ of ART was used. The combination of ART/MQ has been used in the malaria clinics of the Office of Disease Prevention and Control in these southernmost provinces since 2004. However, a few hospitals in the area might use other regimens such as a combination of QN/doxycycline. In addition, in Thailand, vivax malaria shares similar endemic areas with falciparum malaria. Thus, CQ, the first-line treatment for vivax malaria could cause a drug pressure and influence the distribution of the $p f m d r 1$ polymorphisms, especially where vivax malaria was predominant.

The distribution of the $p f m d r 1$ polymorphisms in each area along the international border of Thailand might be influenced by the parasites from neighbouring countries via human movement. Indeed, approximately half of malaria cases in Thailand have been foreign migrant workers [34]. A few studies of the parasites from the Thai-Cambodia border showed that most parasites collected either from Thailand or Cambodia shared a similar genotype, i e, the pfmdr1 184F allele [29,30]. A recent study showed a high level of genetic diversity in the parasites from the Thai-Myanmar and Thai-Cambodia border where cross-border migrations commonly occurred [35]. This study also identified the parasites with the same genotype in patients who were infected in Thailand and Myanmar [35]. In contrast, an identical haplotype was 
found in all parasites collected from Yala. Similar to this previous study, nearly all parasites collected from three provinces of the Thai-Malaysia border, including Yala, contained the similar $p f m d r 1$ genotype, the $86 \mathrm{Y}$ allele. The distribution of the $p f m d r 1$ polymorphisms in the parasites from these three southernmost provinces of Thailand was different from those from Pahang, Peninsula Malaysia, containing the pfmdr1 N86 allele in most isolates [36]. Low variation of the parasite population in this area could be due to recent expansion of the local parasites with fewer introductions of the parasites with other genotypes in the area. Foreign migrant workers in this area were fewer compared to the Thai-Myanmar area, such as Ranong, because of political unrest.

All adapted $P$. falciparum isolates from Yala exhibited a CQ-resistant phenotype. These parasites were QN- and MQ- sensitive. In vitro drug susceptibility pattern of the adapted $P$. falciparum isolates in this study was similar to the results of the study by Rungsihirunrat et al. [37]. Although the pfcrt 76T allele has been proved to be a key determinant for in vitro CQ resistance, the polymorphisms of $p f m d r 1$ gene could modulate the level of CQ resistance $[9,10]$. Besides, the $86 \mathrm{Y}$ allele was also identified as the predictor of CQ treatment failure [38]. It has been shown that parasites with different resistant phenotypes and genotypes exhibited different levels of fitness which might explain the unique parasite structure of $P$. falciparum in the Thai-Malaysia border. The influence of parasites' fitness was indicated when CQ-sensitive strains were reemerging in some countries where CQ use was discontinued because of widespread CQ resistance [39,40]. Using allelic replacement technique, insertion of the 7G8, CQresistant alleles into CQ-sensitive strain, D10 resulted in the loss of parasites' fitness [41]. In contrast, a recent study of clinical samples showed that the parasites with the pfindr1 86Y and D1246 alleles had the fitness advantage over others [42]. Moreover, the parasites with the pfmdr1 $86 \mathrm{Y}$ allele could produce a higher number of gametocytes [43] which would gain the advantage in term of transmission.

\section{Conclusion}

A nationwide implementation of a three-day ART instead of a two-day ART in combination with two-day MQ regimen has been started in Thailand since 2008 to overcome a low cure rate in some areas [1]. However, a new fixed dose ACT will inevitably be considered by the Ministry of Public Health in the near future. The present study showed that $P$. falciparum isolated from different areas along the international border of Thailand exhibited different resistant phenotypic and genotypic patterns. This information will be useful for anti-malarial drug policy in Thailand. New candidate drugs should be adopted at least based on their activity against these phenotypic and genotypic parasites in different areas of Thailand.
Competing interests

The authors declare that they have no competing interests.

\section{Authors' contributions}

MM and SL conceived of the study, participated in the design and coordination of the study and performed the statistical analysis. SI, PS, SA and ST carried out the field works. NSu performed molecular analysis. NSi carried out the in vitro cultivation and sensitivity test. All authors read and approved the final manuscript.

\section{Acknowledgements}

This study was financially supported by the Office of Research Development, Ministry of Defence, Thailand and Phramongkutklao Research Fund.

\section{Author details}

'Department of Parasitology, Phramongkutklao College of Medicine, Ratchawithi Rd, Bangkok 10400, Thailand. ${ }^{2}$ Office of Disease Prevention and Control 12, Department of Disease Control, Ministry of Public Health, Songkhla 90000, Thailand. ${ }^{3}$ Vecter Born Disease Control Center 12.1, Ministry of Public Health, Yala 95000, Thailand. ${ }^{4}$ Office of Disease Prevention and Control 11, Ministry of Public Health, Nakonsitammarat 80000, Thailand.

Received: 25 December 2013 Accepted: 22 March 2014

Published: 27 March 2014

\section{References}

1. WHO: Global Report on Antimalarial Drug Efficacy and Drug Resistance 20002010. Geneva: World Health Organization; 2010.

2. WHO: Guidelines for the Treatment of Malaria. Geneva: World Health Organization; 2006.

3. Noedl H, Se Y, Schaecher K, Smith BL, Socheat D, Fukuda MM, Artemisinin Resistance in Cambodia 1 (ARC1) Study Consortium: Evidence of artemisinin-resistant malaria in western Cambodia. N Engl J Med 2008, 359:2619-2620.

4. Dondorp AM, Nosten F, Yi P, Das D, Phyo AP, Tarning J, Lwin KM, Ariey F, Hanpithakpong W, Lee SJ, Ringwald P, Silamut K, Imwong M, Chotivanich K, Lim P, Herdman T, An SS, Yeung S, Singhasivanon P, Day NP, Lindegardh N, Socheat $\mathrm{D}$, White $\mathrm{NJ}$ : Artemisinin resistance in Plasmodium falciparum malaria. N Engl J Med 2009, 361:455-467.

5. Fidock DA, Nomura T, Talley AK, Cooper RA, Dzekunov SM, Ferdig MT, Ursos LM, Sidhu AB, Naudé B, Deitsch KW, Su XZ, Wootton JC, Roepe PD, Wellems TE: Mutations in the $P$. falciparum digestive vacuole transmembrane protein PfCRT and evidence for their role in chloroquine resistance. Mol Cell 2000, 6:861-871

6. Cooper RA, Ferdig MT, Su XZ, Ursos LM, Mu J, Nomura T, Fujioka H, Fidock DA, Roepe PD, Wellems TE: Alternative mutations at position 76 of the vacuolar transmembrane protein PfCRT are associated with chloroquine resistance and unique stereospecific quinine and quinidine responses in Plasmodium falciparum. Mol Pharmacol 2002, 61:35-42.

7. Foote SJ, Kyle DE, Martin RK, Oduola AM, Forsyth K, Kemp DJ, Cowman AF: Several alleles of the multidrug-resistance gene are closely linked to chloroquine resistance in Plasmodium falciparum. Nature 1990, 345:255-258.

8. Reed MB, Saliba KJ, Caruana SR, Kirk K, Cowman AF: Pgh1 modulates sensitivity and resistance to multiple antimalarials in Plasmodium falciparum. Nature 2000, 403:906-909.

9. Babiker HA, Pringle SJ, Abdel-Muhsin A, Mackinnon M, Hunt P, Walliker D: Highl-level chloroquine resistance in Sudanese isolates of Plasmodium falciparum is associated with mutations in the chloroquine resistance transporter gene pfcrt and the multidrug resistance gene pfmdr1. J Infect Dis 2001, 183:1535-1538.

10. Setthaudom C, Tan-ariya P, Sitthichot N, Khositnithikul R, Suwandittakul N, Leelayoova S, Mungthin M: Role of Plasmodium falciparum chloroquine resistance transporter and multidrug resistance 1 genes on in vitro chloroquine resistance in isolates of Plasmodium falciparum from Thailand. Am J Trop Med Hyg 2011, 85:606-611.

11. Wilson CM, Volkman SK, Thaithong S, Martin RK, Kyle DJ, Milhous WK, Wirth DF: Amplification of pfmdr1 associated with mefloquine and halofantrine resistance in Plasmodium falciparum from Thailand. Mol Biochem Parasitol 1993, 57:151-160. 
12. Cowman AF, Galatis D, Thompson JK: Selection for mefloquine resistance in Plasmodium falciparum is linked to amplification of the pfmdr1 gene and cross-resistance to halofantrine and quinine. Proc Natl Acad Sci U S A 1994, 91:1143-1147.

13. Pickard AL, Wongsrichanalai C, Purfield A, Kamwendo D, Emery K, Zalewski C, Kawamoto F, Miller RS, Meshnick SR: Resistance to antimalarials in Southeast Asia and genetic polymorphisms in pfmdr1. Antimicrob Agent Chemother 2003, 47:2418-2423.

14. Nelson AL, Purfield A, McDaniel P, Uthaimongkol N, Buathong N, Sriwichai S, Miller RS, Wongsrichanalai C, Meshnick SR: Pfmdr1 genotyping and in vivo mefloquine resistance on the Thai-Myanmar border. Am J Trop Med Hyg 2005, 72:586-592.

15. Duraisingh MT, Cowman AF: Contribution of the pfmdr1 gene to antimalarial drug-resistance. Acta Trop 2005, 94:181-190.

16. Duraisingh MT, Jones $P$, Sambou I, von Seidlein $L$, Pinder M, Warhurst DC: The tyrosine- 86 allele of the pfmdr 1 gene of Plasmodium falciparum is associated with increased sensitivity to the anti-malarials mefloquine and artemisinin. Mol Biochem Parasitol 2000, 108:12-23.

17. Poyomtip T, Suwandittakul N, Sitthichot N, Khositnithikul R, Tan-ariya P, Mungthin M: Polymorphisms of the pfmdr1 but not the pfnhe-1 gene is associated with in vitro quinine sensitivity in Thai isolates of Plasmodium falciparum. Malar J 2012, 11:7.

18. Mungthin M, Khositnithikul R, Sitthichot N, Suwandittakul N, Wattanaveeradej $\mathrm{V}$, Ward SA, Na-Bangchang K: Association between the pfmdr1 gene and in vitro artemether and lumefantrine sensitivity in Thai isolates of Plasmodium falciparum. Am J Trop Med Hyg 2010, 83:1005-1009.

19. Snounou G, Viriyakosol S, Jarra W, Thaithong S, Brown KN: Identification of the four human malaria parasite species in field samples by the polymerase chain reaction and detection of a high prevalence of mixed infections. Mol Biochem Parasitol 1993, 58:283-292.

20. Trager $W$, Jensen JB: Human malaria parasites in continuous culture. Science 1976, 193:673-675.

21. Desjardins RE, Canfield J, Haynes D, Chulay JD: Quantitative assessment of antimalarial activity in vitro by a semiautomated microdilution technique. Antimicrob Agents Chemother 1979, 16:710-718.

22. Wooden J, Gould EE, Paull AT, Sibley CH: Plasmodium falciparum: a simple polymerase chain reaction method for differentiating strains. Exp Parasitol 1992, 75:207-212.

23. Djimdé A, Doumbo OK, Cortese JF, Kayentao K, Doumbo S, Diourté Y, Dicko A Su XZ, Nomura T, Fidock DA, Wellems TE, Plowe CV, Coulibaly D: A molecular marker for chloroquine-resistant falciparum malaria. N Engl J Med 2001 344:257-263.

24. Duraisingh MT, Roper C, Walliker D, Warhurst DC: Increased sensitivity to the antimalarials mefloquine and artemisinin is conferred by mutations in the pfmdr1 gene of Plasmodium falciparum. Mol Microbiol 2000, 36:955-961

25. Price RN, Uhlemann AC, Brockman A, McGready R, Ashley E, Phaipun L, Patel R, Laing K, Looareesuwan S, White NJ, Nosten F, Krishna S: Mefloquine resistance in Plasmodium falciparum and increased pfmdr1 gene copy number. Lancet 2004, 364:438-447.

26. Bickii J, Basco LK, Ringwald P: Assessment of three in vitro tests and an in vivo test for chloroquine resistance in Plasmodium falciparum clinical isolates. J Clin Microbiol 1998, 36:243-247.

27. Basco LK, Le Bras J: In vitro susceptibility of Cambodian isolates of Plasmodium falciparum to halofantrine, pyronaridine and artemisinin derivatives. Ann Trop Med Parasitol 1994, 88:137-144.

28. Hatin I, Trape JF, Legros F, Bauchet J, Le Bras J: Susceptibility of Plasmodium falciparum strains to mefloquine in an urban area in Senegal. Bull World Health Org 1992, 70:363-367.

29. Mungthin M, Suwandittakul N, Chaijaroenkul W, Rungsrihirunrat $K$, Harnyuttanakorn P, Seugorn A, Na Bangchang K: The patterns of mutation and amplification of Plasmodium falciparum pfcrt and pfmdr1 genes in Thailand during the year 1988 to 2003. Parasitol Res 2010, 107:539-545.

30. Vinayak S, Alam MT, Sem R, Shah NK, Susanti Al, Lim P, Muth S, Maguire JD, Rogers WO, Fandeur T, Barnwell JW, Escalante AA, Wongsrichanalai C, Ariey F, Meshnick SR, Udhayakumar V: Multiple genetic backgrounds of the amplified Plasmodium falciparum multidrug resistance (pfmdr1) gene and selective sweep of 184 F mutation in Cambodia. J Infect Dis 2010, 201:1551-1560.

31. Phompradit P, Wisedpanichkij R, Muhamad P, Chaijaroenkul W, Na-Bangchang K: Molecular analysis of pfatp6 and pfmdr1 polymorphisms and their association with in vitro sensitivity in Plasmodium falciparum isolates from the Thai-Myanmar border. Acta Trop 2011, 120:130-135.

32. Rojanawatsirivej C, Vijaykadga S, Amklad I, Wilairatna P, Looareesuwan S: Monitoring the therapeutic efficacy of antimalarials against uncomplicated falciparum malaria in Thailand. Southeast Asian J Trop Med Public Health 2003, 34:536-541.

33. Vijaykadga S, Rojanawatsirivej C, Cholpol S, Phoungmanee D, Nakavej A, Wongsrichanalai C: In vivo sensitivity monitoring of mefloquine monotherapy and artesunate-mefloquine combinations for the treatment of uncomplicated falciparum malaria in Thailand in 2003. Trop Med Int Health 2006, 11:211-219.

34. WHO: Malaria in the Greater Mekong Subregion: Regional and Country Profiles. Geneva: World Health Organization; 2010.

35. Pumpaibool T, Arnathau C, Durand P, Kanchanakhan N, Siripoon N, Suegorn A, Sitthi-Amorn C, Renaud F, Harnyuttanakorn P: Genetic diversity and population structure of Plasmodium falciparum in Thailand, a low transmission country. Malar J 2009, 8:155.

36. Atroosh WM, Al-Mekhlafi HM, Mahdy MA, Surin J: The detection of pfcrt and pfmdr1 point mutations as molecular markers of chloroquine drug resistance, Pahang, Malaysia. Malar J 2012, 11:251.

37. Rungsihirunrat K, Chaijareonkul W, Seugorn A, Na-Bangchang K, Thaithong S: Association between chloroquine resistance phenotypes and point mutations in pfcrt and pfmdr1 in Plasmodium falciparum isolates from Thailand. Acta Trop 2009, 109:37-40.

38. Andriantsoanirina V, Ratsimbasoa A, Bouchier C, Tichit M, Jahevitra M, Rabearimanana S, Raherinjafy R, Mercereau-Puijalon O, Durand R, Ménard D: Chloroquine clinical failures in P. falciparum malaria are associated with mutant Pfmdr-1, not Pfcrt in Madagascar. PLoS One 2010, 5:e13281.

39. Kublin JG, Cortese JF, Njunju EM, Mukadam RA, Wirima JJ, Kazembe PN, Djimdé AA, Kouriba B, Taylor TE, Plowe CV: Reemergence of chloroquinesensitive Plasmodium falciparum malaria after cessation of chloroquine use in Malawi. J Infect Dis 2003, 187:1870-1875.

40. Wang X, Mu J, Li G, Chen P, Guo X, Fu L, Chen L, Su X, Wellems TE: Decreased prevalence of the Plasmodium falciparum chloroquine resistance transporter $76 \mathrm{~T}$ marker associated with cessation of chloroquine use against $P$. falciparum malaria in Hainan, People's Republic of China. Am J Trop Med Hyg 2005, 72:410-414.

41. Hayward R, Saliba KJ, Kirk K: Pfmdr1 mutations associated with chloroquine resistance incur a fitness cost in Plasmodium falciparum. Mol Microbiol 2005, 55:1285-1295.

42. Ochong E, Tumwebaze PK, Byaruhanga O, Greenhouse B, Rosenthal PJ: Fitness consequences of Plasmodium falciparum pfmdr1 polymorphisms inferred from ex vivo culture of Ugandan parasites. Antimicrob Agents Chemother 2013 [Epub ahead of print].

43. Osman ME, Mockenhaupt FP, Bienzle U, Elbashir MI, Giha HA: Field-based evidence for linkage of mutations associated with chloroquine (pfcrt/ pfmdr1) and sulfadoxine-pyrimethamine ( $p f d h f r / p f d h p s)$ resistance and for the fitness cost of multiple mutations in P. falciparum. Infect Genet Evol 2007, 7:52-59.

doi:10.1186/1475-2875-13-117

Cite this article as: Mungthin et al.: Distribution of $p f m d r 1$ polymorphisms in Plasmodium falciparum isolated from Southern Thailand. Malaria Journal 2014 13:117.

\section{Submit your next manuscript to BioMed Central and take full advantage of:}

- Convenient online submission

- Thorough peer review

- No space constraints or color figure charges

- Immediate publication on acceptance

- Inclusion in PubMed, CAS, Scopus and Google Scholar

- Research which is freely available for redistribution 